\title{
Influence of phytodetrital quality on macroinfaunal community structure and epifaunal response
}

\author{
Neus Campanyà-Llovet ${ }^{1,2, *}$, Paul V. R. Snelgrove ${ }^{1,2}$ \\ ${ }^{1}$ Biology Department, Memorial University of Newfoundland, St. John's, NL A1B 3X9, Canada \\ ${ }^{2}$ Department of Ocean Sciences, Memorial University of Newfoundland, St. John's, NL A1C 5S7, Canada
}

\begin{abstract}
In order to evaluate the influence of food quality on deep-sea macroinfaunal and mega-epifaunal communities, we deployed experimental food pulses at $890 \mathrm{~m}$ depth in Barkley Canyon, NE Pacific. Pulses of 2 microalgal species (i.e. Chaetoceros calcitrans and Nannochloropsis oculata) differed in nitrogen, carotenoid, and lipid content (i.e. quality). After 8 mo, we sampled the enriched patches and controls with push cores. The community structure between the 2 treatments differed in the deeper sediment layers $(5-10 \mathrm{~cm})$. Despite no significant differences in the surface sediments $(0-5 \mathrm{~cm})$ among the 2 enrichment patches and the control, the macroinfaunal community from sediments enriched with $N$. oculata separated in ordination space. These results suggest that the experimental duration exceeded the appropriate time-frame to detect initial colonizers at the surface sediments. Analyses of functional traits, including migration, colonization, foraging, and food selectivity, separated communities in ordination space among algal treatments and control, although not significantly. Based on fixed camera images of each treatment over the course of the experiment, we observed more epifaunal Brachyura visits (between 50 and 40 more) to a patch enriched with $N$. oculata than to a patch enriched with $C$. calcitrans or the procedural control patch during the first 2 wk of the experiment. The visible area of 1 enrichment patch per algal treatment disappeared ( $>90 \%) \sim 1.5$ mo after deployment. Our study points to influences of food quality, at the algal class level, on macroinfaunal community structure and function, epifaunal disturbance, and sediment reworking.
\end{abstract}

KEY WORDS: Food quality $\cdot$ Food pulse $\cdot$ Deep sea $\cdot$ Infauna $\cdot$ Megafauna $\cdot$ Sediments

\section{INTRODUCTION}

Several lines of evidence emphasize the importance of differences in quantity (e.g. Grassle \& Morse-Porteous 1987) and quality (e.g. Ginger et al. 2001, Snelgrove et al. 1992, 1994, 1996, Wolff et al. 2011) of food supply in structuring deep-sea benthic communities (macrofauna and megafauna), however, direct evidence remains scant. This gap limits our understanding of how food supply influences biodiversity patterns and biogeography of deep-sea ecosystems, noting that food supply can also influence ecosystem functioning and services (e.g. carbon recycling) (Levin et al. 2001, Snelgrove \& Smith

*Corresponding author: ncil58@mun.ca
2002). Expected changes in food supply from surface waters to the deep-sea benthos associated with climate change (Smith et al. 2008, Sweetman et al. 2017) add urgency in understanding how food quality influences one of the largest species pools on Earth (Snelgrove \& Smith 2002). Furthermore, recent studies suggest contrasting responses to changes in food supply in deep-sea ecosystems compared to their shallow-water counterparts. For example, Yool et al. (2017) predicted decreased biomass in deepsea ecosystems with expected reduced particulate organic carbon (POC) fluxes, but increases in shallow water in future climate scenarios. Campanyà-Llovet et al. (2017) also reported changing abundances in

() The authors 2019. Open Access under Creative Commons by Attribution Licence. Use, distribution and reproduction are unrestricted. Authors and original publication must be credited. 
deep-sea macrofaunal abundances with changes in the quality of sedimentary organic matter, in contrast with shallow-water environments.

The quality of a particular food source can be defined as the degree to which quantity and composition of that food source fulfill consumer nutritional needs (Müller-Navarra 2008), and food quality can play a role in structuring communities and food-web structure (Wolff et al. 2011, Campanyà-Llovet et al. 2017). Most evidence on the role of food quality for marine organisms comes from the field of aquaculture, which optimizes diets to enhance growth, survival, and reproductive outputs of the reared species (Glencross 2009). Nitrogen content, degradation state (Beaulieu 2002), biopolymeric carbon (i.e. carbohydrates, lipids, and proteins; Pusceddu et al. 2011), fatty acids and sterols (Parrish 2013), and algal pigment composition (Roy et al. 2011) all represent potentially important sources of variation in food quality for benthic organisms.

Several studies on megafauna and macrofauna suggest specific benefits for organisms from food sources differing in quality. For example, some carotenoids and lipids improve reproductive output of invertebrates, particularly echinoderms (Tsushlma et al. 1997, Glencross 2009), which can feed selectively on food patches containing specific carotenoids or fatty acids (Ginger et al. 2001, Wigham et al. 2003, Neto et al. 2006, Boon \& Duineveld 2012), resulting in dramatic shifts in benthic communities (Billett et al. 2010). Furthermore, structural changes in benthic communities and food webs can influence ecosystem processes such as bioturbation (Dauwe et al. 1998). Polychaetes, the dominant macroinfaunal group in our Barkley Canyon study site (Campanyà-Llovet et al. 2018), can feed selectively on particles differing in size and/or biochemistry (Galéron et al. 2001, Jumars et al. 2015). Other examples of organisms with a capacity for selective feeding include oligochaetes, which select particles of specific grain size and organic richness (Rodriguez et al. 2001), and mussels, which select for specific particle sizes (Defossez \& Hawkins 1997). Some nematodes and benthic harpacticoids exhibit selective feeding at a finer level (finer than bulk organic matter or biopolymeric carbon such as proteins, carbohydrates, and lipids), differentiating between diatoms and bacteria (Azovsky et al. 2005, Ingels et al. 2010, Estifanos et al. 2013). In shallow water, oysters and harpacticoids can feed selectively on different classes of phytoplankton and even different species of diatoms (Loret et al. 2000, Cognie et al. 2001). Heart urchins Echinocardium cordatum from the North Sea actively select for fatty acids and chlorophyll a (chl a) (Boon \& Duineveld 2012). Changes in food quality may favour some selective benthic feeders, broadly affecting community structure.

The 'patch mosaic' theory posits that food patchiness and disturbance enhance overall numbers of species, explaining in part the unexpectedly high diversity in the deep sea (Grassle \& Sanders 1973). Colonization experiments consisting of enriched trays with contrasting food sources at different degradation stages showed food selectivity at the colonization stage (Snelgrove et al. 1992, 1994, 1996). More recent studies have traced food uptake by isotopically labelling the food added to the sediments, in 'pulse-chase' experiments (Witte et al. 2003, Mäkelä et al. 2017). This type of experiment delineates trophic pathways and identifies the taxa that dominate and/or initiate food uptake from differing food sources (Hunter et al. 2013, Jeffreys et al. 2013). Our study focused on changes in macrofaunal community structure with varying qualities of food (i.e. phytoplankton classes differing not only in nitrogen content but also in lipid and pigment composition). Most previous deep-sea experiments have either altered sediments when enriching them or confined the added food within a mesocosm for the duration of the experiment, thus constraining the entrance/exit of organisms in the experimental area. In contrast, adding food to otherwise undisturbed sediments, without barriers to migration, adds realism to the experiment (Smith \& Brumsickle 1989, Jeffreys et al. 2011). Changes in macroinfaunal community structure have been reported after pulses of high-quality phytodetritus in shallow water (Quijón et al. 2008), among naturally occurring patches of more or less degraded seagrass (Gallmetzer et al. 2005), and following the addition of wood or brown macroalgae to the deep sea floor (Grassle \& Morse-Porteous 1987).

Enrichment experiments are time-sensitive. For example, numbers of individuals and species in mudflat sediments enriched with green macroalgae decreased within the first 2 mo of the experiment, then increased after about $4 \mathrm{mo}$, and finally declined to background abundances 5 mo later after detrital resources were depleted (Kelaher \& Levinton 2003). Quijón et al. (2008) observed changes in macroinfaunal community structure $1 \mathrm{wk}$ after but not 5 mo after the addition of an algal pulse. Furthermore, algae added in the fall produced a greater impact on the benthic community than when added during the summer. 'Pulse-chase' experiments demonstrate macroinfaunal uptake of organic matter within a few days of addition (Witte et al. 2003, Hunter et al. 2013, 
Mäkelä et al. 2017), but colonization of food patches and changes in community structure typically become evident after weeks or months (Snelgrove et al. 1996, Galéron et al. 2001). Specific environmental variables and community structure determine the time response to food enrichments in each ecosystem.

In order to test the effects of food quality on Barkley Canyon benthos, we selected 2 biochemically distinct algal species for our in situ experiment. The 2 species differ in nitrogen content but also represent different algal classes, which implicitly affects their lipid and pigment composition. We chose the diatom Chaetoceros calcitrans to mimic the spring phytoplankton bloom, and the euglenophyte Nannochloropsis oculata for its high lipid content (Liu et al. 2017). N. oculata has been widely used in aquaculture because of its high polyunsaturated fatty acid (PUFA) and sterol content (Cohen. 1999). We aimed to quantify the consequences of contrasting food pulses on deep-sea benthic ecosystems by (1) identifying shifts in macroinfaunal community structure between patches differing in food quality; (2) monitoring the number of visits of different epifaunal species to food patches differing in quality with time; and (3) comparing food patch disappearance, and therefore, longevity, between algal treatments.

\section{MATERIALS AND METHODS}

\subsection{Experimental deployment and recovery}

We deployed a food enrichment experiment at Barkley submarine canyon (890 m) (Fig. 1) on 11 September 2013 from the vessel RV 'Falkor' using the remotely operated vehicle (ROV) ROPOS (www. ropos.com). The location of the experiment corresponded to the MidWest platform of the Ocean Networks Canada (ONC; www.oceannetworkscanada. ca) observatory. Food quality and quantity in Barkley Canyon vary with depth (Campanyà-Llovet et al. 2018); sediments at the MidWest platform are characterized by high amounts (total organic carbon [TOC]: $1.94 \pm 0.2 \%$; mean $\pm \mathrm{SD}$ ) of relatively high quality (high concentrations of total lipids: $362.3 \pm 244.8 \mu \mathrm{g}$ $\mathrm{g}^{-1}$ and low $\mathrm{C}: \mathrm{N}$ ratio: $9.5 \pm 0.81$ ), though relatively degraded (low chl a:pheophorbides ratio: $0.12 \pm 0.06$ ) organic matter compared to other stations within the canyon (Campanyà-Llovet et al. 2018). The presence of an oxygen minimum zone (OMZ; 400-1000 m depth; $0.17-0.18 \mathrm{ml} \mathrm{O}_{2} \mathrm{l}^{-1}$ at the sampling site) within the canyon (Keeling et al. 2010, Domke et al. 2017) likely limits macroinfaunal densities compared to those reported in the North Carolina margin (NE Pacific) outside the OMZ (Levin et al. 2003).

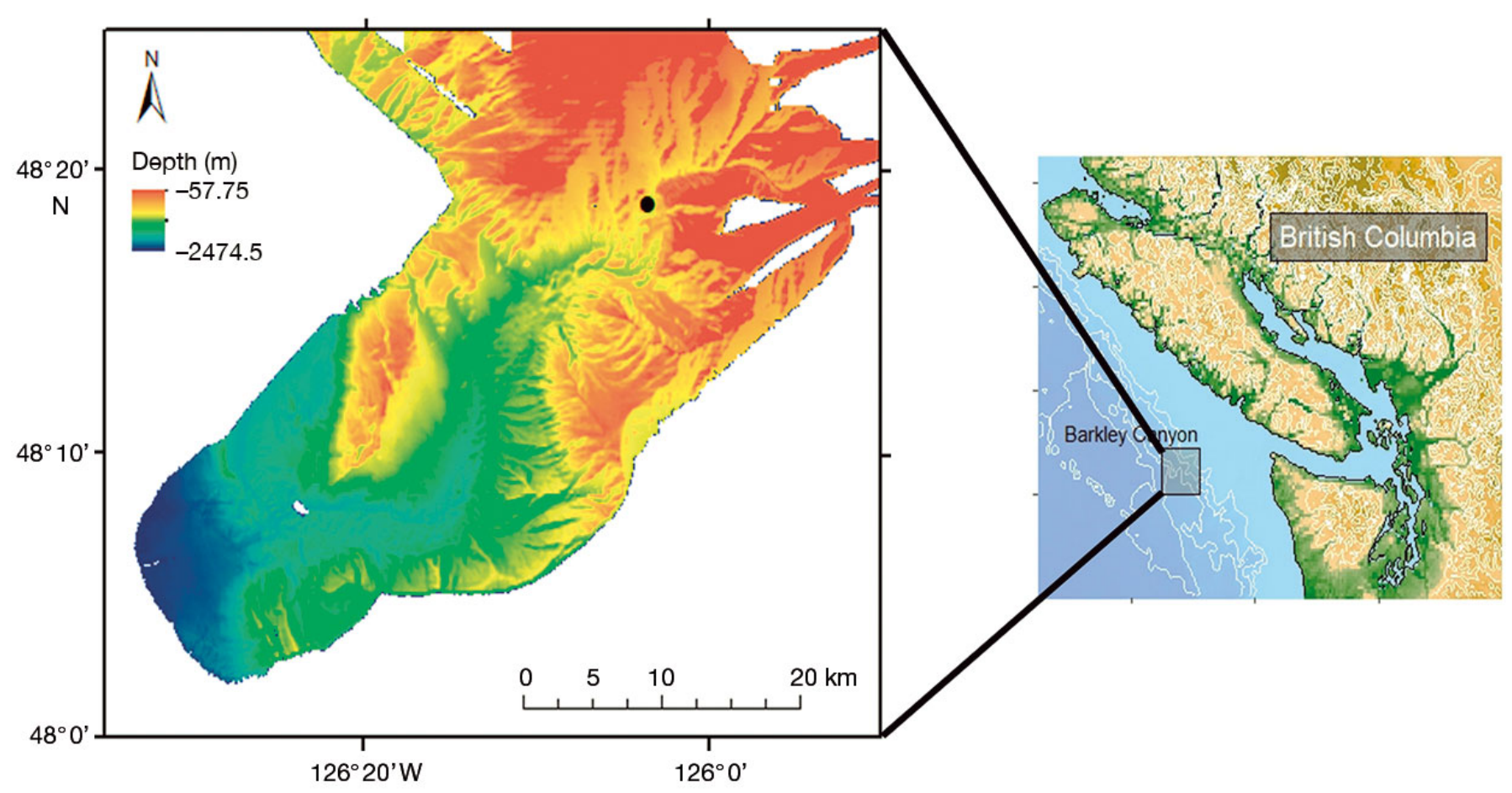

Fig. 1. Enrichment experiment location within Barkley Canyon (NE Pacific). Bathymetric map generated from 2 original rasters sampled from the RV 'TG Thompson' in 2012 and RV 'Falkor' in 2013 by Ocean Networks Canada 
The algae were obtained from the Dr. Joe Brown Aquatic Research Building (www.mun.ca/osc/jbarb/ index.php). We spread the same amount (88.2 mg) of organic carbon onto the sediment to generate an organic matter 'patch', using either the North Pacific diatom Chaetoceros calcitrans or the Eustigmatophycea Nannochloropsis oculata; this organic input corresponds to the maximum flux of organic matter arriving at $500 \mathrm{~m}$ depth in Barkley Canyon $\left(60 \mathrm{mg} \mathrm{C} \mathrm{m}^{-2} \mathrm{~d}^{-1}\right.$; Wu et al. 1999) integrated over a 1 mo period. In addition to the implicit differences in lipid and pigment composition of algae from 2 different classes that differ in food quality, we measured total organic carbon and nitrogen (see Section 2.2. below) to evaluate differences in food quality at a bulk level. Lipid and pigment composition of the algal treatment could not be measured because of constraints on storage conditions $\left(-20^{\circ} \mathrm{C}\right)$ and sampling facilities.

The algae were spread onto the seafloor using an Oceanlab spreader borrowed from Dr. Ursula Witte, Oceanlab, University of Aberdeen, Scotland, UK (Hunter et al. 2013). Each spreader consisted of a polycarbonate tube (diameter: $25 \mathrm{~cm}$, length: $30 \mathrm{~cm}$ ) with a plunger mechanism that released the treatment upon triggering. The resulting patches could potentially cover an area of $490 \mathrm{~cm}^{2}$; however, actual distributions were non-homogenous and were concentrated in approximately $25 \%$ of the area $\left(122.5 \mathrm{~cm}^{2}\right)$. Therefore the approximate algal addition was $0.72 \mathrm{mgC} \mathrm{cm}^{-2}$ overall, but varied in concentration across the patch. We left the spreaders in place for between 4 and $6.5 \mathrm{~h}$ to allow the treatment to settle, taking into account a minimum reported settling time of $30 \mathrm{~min}$ to $2 \mathrm{~h}$ (Fornes et al. 1999, Hunter et al. 2012). To expedite settlement of the algae, we mixed it with inert kaolin clay (Fornes et al. 1999, Hunter et al. 2012) (40 g patch $\left.{ }^{-1}\right)$, which added a clear white color to the enrichment patch that distinguished it from surrounding sediments. Given our concern that strong bottom currents (up to $20 \mathrm{~cm} \mathrm{~s}^{-1}$ in Barkley Canyon; Thomsen et al. 2012) or megafaunal activity would disperse the algae, we added $0.5 \mathrm{~g}$ of inert fluorescent tracer to provide visible evidence of patch presence when we re-sampled at the end of the experiment. In the end, the kaolin clay clearly stood out from the background sediment and proved a better marker than the fluorescent tracer. To minimize disturbance by the abundant sablefish Anoplopoma fimbria, we placed cage frames $(50 \times 50 \times$ $40 \mathrm{~cm}$, no mesh) over each treatment patch. One video record showed a sablefish clearly diverted by the cages from swimming on top of the patch (N. Campanyà-Llovet pers. obs.). Because the experi- ment was deployed in front of ONC's AXIS P1347 colour camera with 2 ROS MV-LED lights and a pan/tilt unit that allowed complete coverage of all 3 treatments $\left( \pm 90^{\circ}\right.$ tilt and $\pm 180^{\circ}$ pan $)$, we could monitor patch disappearance and megafaunal visits to the enrichment patches over time. We could only record 1 patch treatment ${ }^{-1}(N$. oculata, C. calcitrans, and procedural control) owing to the wide spatial extent of the experiment and limited camera availability, precluding any replication. The camera lights were turned on every $2 \mathrm{~h}$ for $5 \mathrm{~min}$, during which time the camera was directed at each treatment and control patch for $80 \mathrm{~s}$. All videos and still imagery are archived and available through ONC's Oceans 2.0.

We placed each patch a minimum of $3 \mathrm{~m}$ away from adjacent patches. We deployed 6 replicates of each algal treatment and 6 cages with no enrichment patch as a control for cage frames (Fig. 2). Limitations of ROV time precluded the deployment of a procedural control with kaolin and fluorescent dye onto sediments protected with cage frames and without algal material. Instead, our procedural control only included cage frames. Background sediment samples provided a natural control. After 8 mo (11 and 12 May 2014), we were finally able to return to the site to recover the experiment using the ROV 'OE' aboard the CCGS 'Tully'. We collected 24 push cores (6 from the background community, 6 from the procedural controls, 6 from C. calcitrans treatments, and 6 from $N$. oculata treatments) to evaluate macroinfaunal community structure and any remaining traces of the algal enrichment. We vertically sectioned each core into $0-5$ and $5-10 \mathrm{~cm}$ layers, removed $4 \mathrm{ml}$ of sediment samples from each core layer using a syringe, and froze them at $-20^{\circ} \mathrm{C}$ in Whirl-Pack bags for later

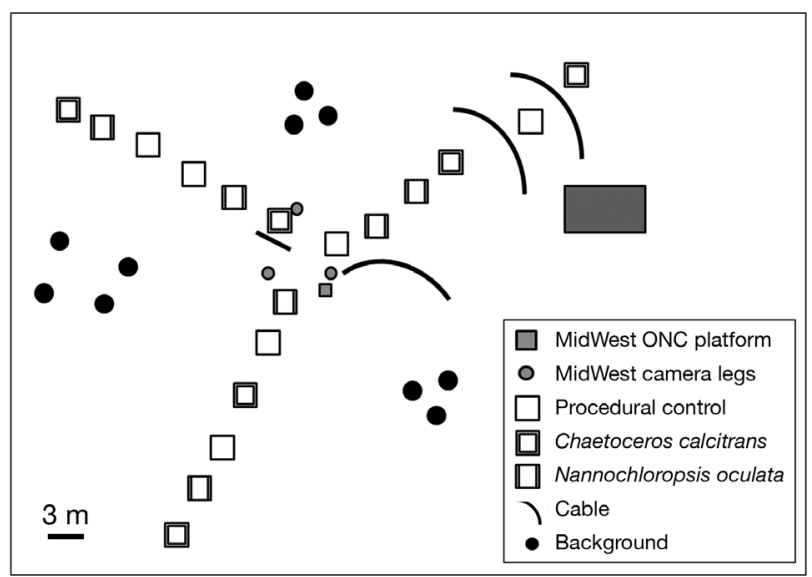

Fig. 2. Food enrichment experiment layout in the MidWest Ocean Networks Canada (ONC) platform at Barkley Canyon. 'Procedural control' controls for the cage frame effects on the benthic communities 
organic matter analysis. The remainder of the core was preserved in a $4 \%$ seawater-formaldehyde solution for taxonomic analysis.

\subsection{Sediment samples}

Organic matter samples were analyzed for TOC as a measure of food quantity and total nitrogen (TN) and $\mathrm{C}: \mathrm{N}$ ratios based on \% weight as measures of food quality (Campanyà-Llovet et al. 2017). We quantified TOC and TN by drying a sediment subsample of $1-5 \mathrm{~g}$ (wet weight) at $80^{\circ} \mathrm{C}$ for $24 \mathrm{~h}$ and grinding the subsample to a fine powder. TOC and TN were determined after de-carbonation of sediments using the acid vapour method (under pure $\mathrm{HCl}$ fumes for 24 h; Yamamuro \& Kayanne 1995), to eliminate inorganic carbon. Acidified sediment samples were dried at $80^{\circ} \mathrm{C}$ for $24 \mathrm{~h}$ prior to analysis and run once using a Carlo Erba NA1500 Series II elemental analyser (EA).

We transferred samples for taxonomic analysis into $70 \%$ ethanol immediately in the laboratory and processed them through a $300 \mu \mathrm{m}$ sieve for identification. Specimens were stained with Rose Bengal, sorted under a dissecting microscope, and identified to the lowest taxonomic level possible using a variety of published sources (Hartman 1968, 1969, Bousfield 1973, Barnard \& Karaman 1991, Blake et al. 1996a,b,c, Reuscher et al. 2009).

\subsection{Video analysis}

In order to determine rates of patch disappearance, we extracted still images from the videos, available in Sea Tube Pro (Oceans 2.0; https://dmas.uvic. ca/SeaTube), from ONC every day from the beginning to the end of the experiment (13 September 2013 until 25 April 2014). We measured the surface area of each patch with 'image J' software (https:// imagej.nih.gov), using the width of the cage frame to calculate scale in each picture.

We estimated the number of epifaunal visits at each food patch and control 4 sampling times each day $(00: 00,06: 00,12: 00$, and 18:00 h) during the first 2 wk of the experiment (13-28 September 2013). We counted and identified the organisms found on the sediment within the area delimited by each cage frame at a broad taxonomic level following Juniper et al. (2013) and Doya et al. (2017), constrained by the lack of physical specimens to confirm species identities.
We further investigated the impact of the cage frames by identifying the taxa and counting the number of individuals from each taxon that interacted with different areas of the cage frame: on top, underneath and in contact with the cage frame, on the legs, at the base of the legs, and on the sediment surface but under the cage frame.

\subsection{Statistical analysis}

\subsubsection{Infauna}

We ran separate statistical analyses for the 2 sediment depths ( $0-5$ and 5-10 cm) because we expected a different response from organisms in the surface sediment layers $(0-5 \mathrm{~cm})$, and therefore in direct contact with the algal treatment, compared to the deeper sediment layers $(5-10 \mathrm{~cm})$, and therefore away from the influence of the food enrichment. We compared macroinfaunal densities and biodiversity (i.e. $\mathrm{ES}_{[10]}$ and rarefaction curves) in each experimental treatment and procedural control. We examined normality of the residuals prior to a 1-way ANOVA (density, log-transformed and biodiversity, no transformation) with 1 fixed factor: treatment (levels: procedural control, C. calcitrans, N. oculata). We could not achieve normality of the residuals in total abundances or biodiversity $\left(\mathrm{ES}_{[10]}\right)$ from the deeper sediment layers and therefore ran a non-parametric test (Kruskal-Wallis). The ANOVAs and Kruskal-Wallis tests $(\alpha=0.05)$ were all done in RStudio v.3.3.0. We then used the multivariate PERMANOVA routine, with 9999 permutations and $\alpha=0.05$, from the add-on PERMANOVA+ module in PRIMER v.6 (Clarke \& Gorley 2006, Anderson et al. 2008) to identify differences in macroinfaunal community structure with the same factors and levels as above. Abundance data were log transformed into Bray-Curtis similarity matrices and zero-adjusted in the deeper sediment layers $(5-10 \mathrm{~cm})$, where organisms were sometimes absent. This correction forced $100 \%$ similarity between 2 samples with no fauna, as is appropriate for such data. We assume that lack of oxygen at those sediment depths $(5-10 \mathrm{~cm})$ affected all samples similarly, and used the zero-adjusted Bray-Curtis similarity method. We used non-metric multidimensional scaling (nMDS) to visualize macroinfaunal community variation with treatment and sediment depth within the ordination space, and superimposed correlation vectors to show the most important taxa in explaining the observed pattern. We complemented these results with the similarity percentage (SIMPER) 
routine, which tests for significant differences in discriminating taxa. We used a PERMANOVA with 1 fixed factor (treatment levels: procedural control, $C$. calcitrans, N. oculata) to assess differences in community structure among treatments in each sediment depth separately. Prior to these analyses, we verified homogeneity of multivariate dispersion using the PERMDISP routine (Anderson et al. 2008). We repeated the same multivariate analyses based on functional traits of the different taxa (Jumars et al. 2015). These traits included life stage (i.e. juvenile and adults, based on size), which differentiate between colonization from larvae that develop into juveniles and horizontal migration of adults; mobility (i.e. sessile [organisms that can feed without moving], discretely motile [organisms that stay in place indefinitely and can feed without moving but remain capable of moving], and motile [organisms that move in order to eat]), which represents the degree of foraging capacity of the organism; and feeding morphology (i.e. palps, tentacles, and pharynx), which indicates the capacity to selectively feed on different food particles, with palps and tentacles as the most selective structures and pharynxes as the least. In order to assess the effect of cage frames on macroinfaunal community structure, we also repeated the uni- and multivariate analyses based on number of species, modifying the 'treatment' factor (levels: procedural control and background). We used a Kruskal-Wallis non-parametric test when comparing total abundances among procedural controls and background samples for the surface and deeper sediment layers because we could not attain normality and homogeneity of variances, even after transformation.

\subsubsection{Sediment organic matter}

We first investigated food quality (i.e. TN and C:N ; Campanyà-Llovet et al. 2017) of the algae used to enrich the sediments with a 1-way ANOVA $(\alpha=0.05)$ with 1 fixed factor (algae: C. calcitrans, N. oculata) in RStudio v.3.3.0. We kept the quantity of food constant between treatments when we deployed the experiment (see Section 2.1. above). We then investigated food quantity and quality in sediments at the end of the experiments. For TN and C:N, we used a 2-way ANOVA with fixed and crossed factors (treatment: procedural control, C. calcitrans, and N. oculata; sediment depth: $0-5$ and 5-10 $\mathrm{cm}$ ). The latter comparison was possible because of the inferred independence of samples between sediment depths (1-way ANOVA, $p>0.05$ ). We also ran a Kruskal-Wallis test for each factor above on TOC because we could not attain normality of the residuals and homogeneity of variances, even after transformation.

\section{RESULTS}

\subsection{Infauna}

In total, we identified 279 individuals representing 77 taxa from 57 cores across 4 different treatments (background, procedural control, Chaetoceros calcitrans, Nannochloropsis oculata). Our multivariate analysis based on species composition showed significant differences between treatments only in the deeper sediment samples $(5-10 \mathrm{~cm})$ (PERMANOVA, Pseudo- $F_{2,15}=1.34, \mathrm{p}_{\text {(perm) }}=0.0362$ ). Pairwise comparisons indicated largest differences among the 2 algal treatments, however, differences were not significant $\left(\mathrm{p}_{(\mathrm{perm})}>0.05\right)$, indicating differences in the effect sizes between each pair. The PERMDISP routine did not identify differences in the data cloud dispersion among treatments (PERMDISP, $F_{2,15}=1.58$, $\mathrm{p}_{(\text {perm })}=0.360$ ). Aricidea simplex, bivalves sp. A, and Aphelochaeta sp. A were the main contributors in the separation of the sediments enriched with $N$. oculata in the deeper layers $(5-10 \mathrm{~cm})$, as shown by the superimposed vectors in the nMDS (Fig. 3).

Multivariate analysis of fauna in surface sediment samples $(0-5 \mathrm{~cm})$ indicated no significant differences (PERMANOVA, Pseudo- $F_{2,15}=0.80, \mathrm{p}=0.786$; PERMDISP, $F_{2,15}=0.12, \mathrm{p}=0.898$ ) in species composition of $N$. oculata treatments, C. calcitrans treatments, and procedural controls. Despite some overlap, treatments nonetheless separated in ordination space (Fig. 3) with a stress value of 0.13 , which differs from a random distribution (stress $>0.2$; Clarke \& Gorley 2006).

Despite non-significant differences among treatments in functional traits ( $p>0.05)$, juveniles in surficial sediments of some samples separated from both algal treatments in nMDS ordination space (Fig. 4). For adults, some surficial sediment samples enriched with C. calcitrans separated from sediments enriched with $N$. oculata and procedural controls, although the high stress in the nMDS representation in this case (0.18) approaches a random distribution $(>0.2$; Clarke \& Gorley 2006), both algal treatments separated from the control when considering only organisms with tentacles as a feeding structure (Fig. 4).

Total abundances did not differ among treatments (i.e. procedural control, C. calcitrans, N. oculata) in surface sediment layers (1-way ANOVA, $F_{2,15}=0.98$, $\mathrm{p}=0$. 397) (Fig. 5a) or in the deeper sediment layers 


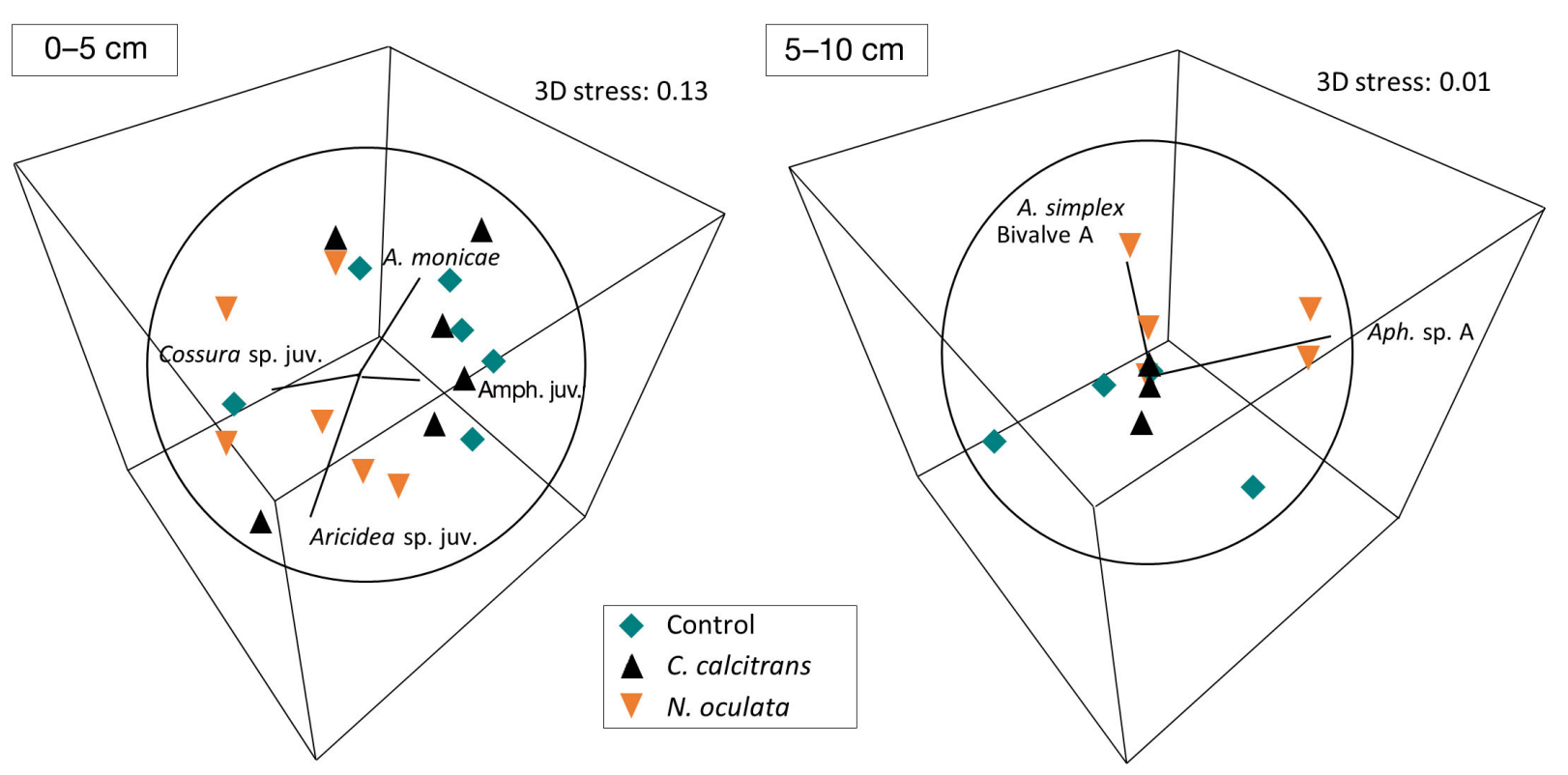

Fig. 3. Three-dimensional non-metric multidimensional scaling (3D nMDS) based on infaunal response to a food enrichment experiment in Barkley Canyon per treatment and per sediment depth. Assemblages are based on Bray-Curtis similarity $\log (x+1)$ transformation. The large circle represents the correlation between species and nMDS axes. We only overlaid the most relevant vectors (Pearson's correlation threshold of 0.75 ) $\mathrm{n}=6$ each for control, Chaetoceros calcitrans, and Nannochloropsis oculata treatments. A. monicae: Aricidea (Stretzovia) monicae; Amph. juv.: Ampharetid juvenile; Aph. sp. A: Aphelochaeta sp. A; A. simplex: Aricidea simplex

(Kruskal-Wallis, $\left.\chi^{2}=1.64, \mathrm{df}=2, \mathrm{p}=0.439\right)$. Similarly, $\mathrm{ES}_{[10]}$ did not vary significantly among treatments in surface sediment layers (1-way ANOVA, $F_{2,15}=0.92$, $\mathrm{p}=0.419$ ) or deeper sediment layers (Kruskal-Wallis, $\chi^{2}=1.55, \mathrm{df}=2, \mathrm{p}=0.460$ ) (Fig. 5b).

We compared the background community with the procedural control assemblages to identify any potential effects of the cage frames (treatment factor levels: procedural control and background) on macroinfaunal community structure. Total abundances did not significantly differ among treatments (i.e. back- ground and procedural control) in the surface sediments (Kruskal-Wallis $\chi^{2}=1.28, \mathrm{df}=1, \mathrm{p}=0.257$ ) or in the deeper sediments (Kruskal-Wallis $\chi^{2}=0.08$, $\mathrm{df}=1, \mathrm{p}=0.768$ ) (Fig. 6a). Similarly, $\mathrm{ES}_{[10]}$ did not vary significantly among treatments (1-way ANOVA, treatment: $\left.F_{1,9}=0.12, \mathrm{p}=0.733\right)$ but did decrease with sediment depth (1-way ANOVA, $F_{1,21}=17.81$, $\mathrm{p}<0.001$ ) (Fig. 6b). PERMANOVA analysis identified no significant differences between background and procedural control samples (Pseudo- $F_{1,9}=0.76, \mathrm{p}=$ 0.779 ), and statistically significant differences only
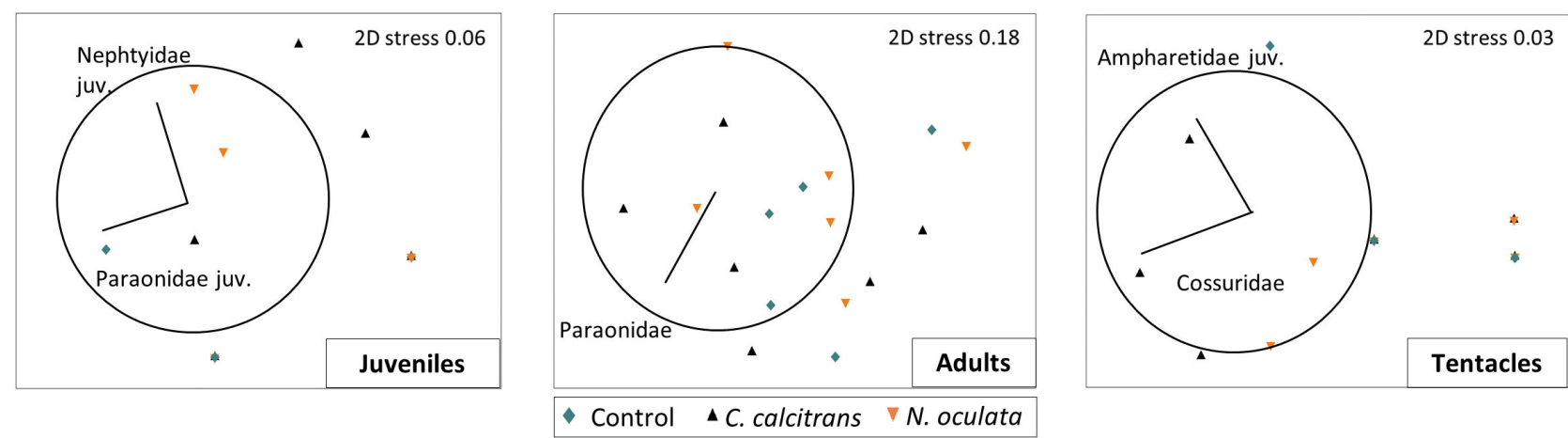

Fig. 4. Two-dimensional non-metric multidimensional scaling (2D nMDS) based on infaunal response to a food enrichment experiment in Barkley Canyon per treatment and per sediment depth based on juveniles, adults, and organisms with tentacles. Assemblages are based on Bray-Curtis similarity $\log (x+1)$ transformation. The large circle represents the correlation between species and nMDS axes. We only overlaid the most relevant vectors (Pearson's correlation threshold of 0.75 ); $\mathrm{n}=6$ each for control, Chaetoceros calcitrans, and Nannochloropsis oculata treatments 

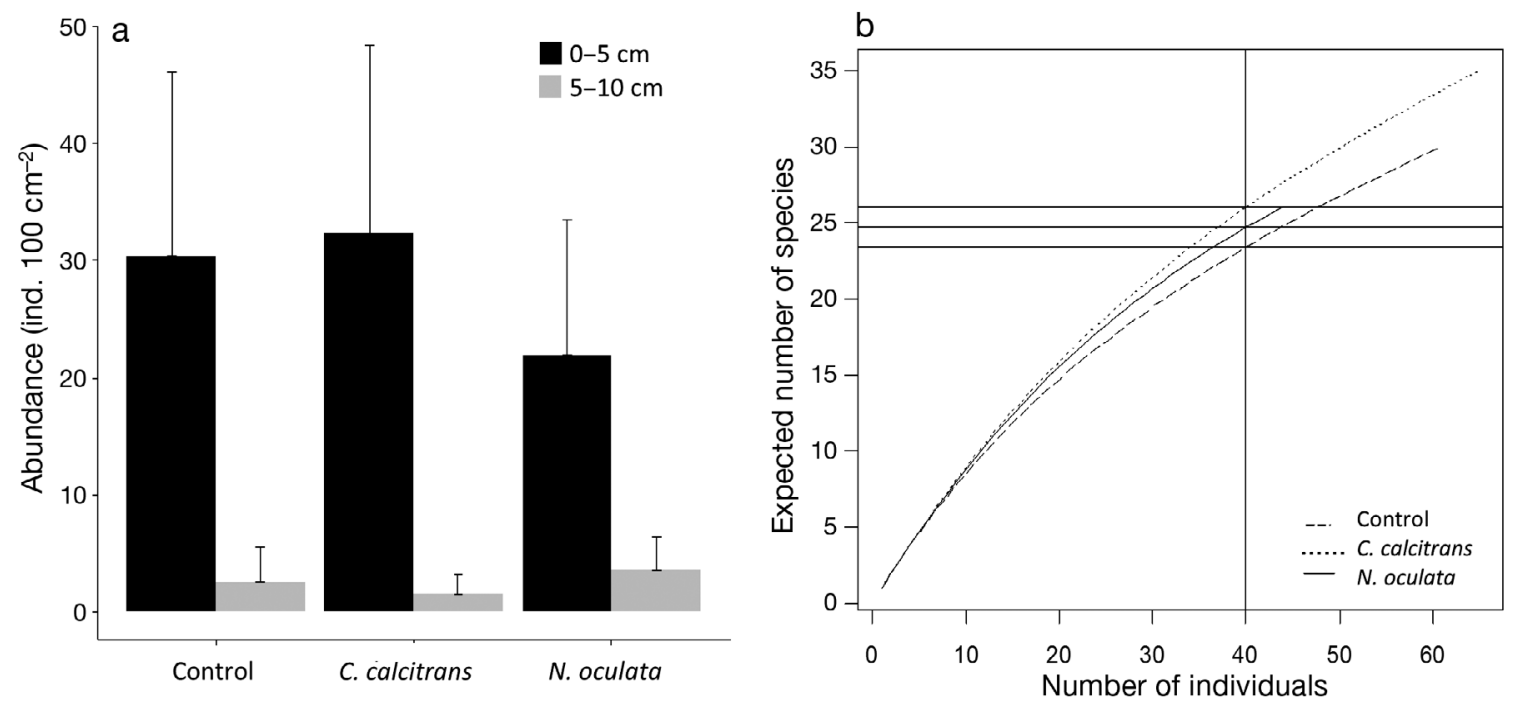

Fig. 5. Effects of food enrichment with different algal classes on macroinfaunal communities from Barkley Canyon: (a) total infaunal abundances per treatment and sediment (error bars: 1 SD); and (b) expected number of species per treatment in surface sediment layer $(0-5 \mathrm{~cm})$; lines denote number of species at 50 individuals. C. calcitrans: Chaetoceros calcitrans; $N$. oculata: Nannochloropsis oculata; $\mathrm{n}=6$ each for control, C. calcitrans and $N$. oculata treatments per sediment layer

between sediment depths (Pseudo- $F_{1,21}=3.94, \mathrm{p}=$ 0.002) (Fig. 7). We found no significant differences in the data cloud dispersion of the procedural control and background samples based on treatment (PERMDISP, $\left.F_{1,9}=0.73, \mathrm{p}_{(\text {perm })}=0.477\right)$ but significant differences based on sediment depth (PERMDISP, $\left.F_{1,21}=72.29, \mathrm{p}_{(\text {perm })}<0.001\right)$.

We measured a significantly higher (1-way ANOVA, $\left.F_{1,5}=7306, \mathrm{p}<0.001\right) \mathrm{C}: \mathrm{N}$ ratio in $N$. oculata $(11.29 \pm 0.15)$ compared to C. calcitrans $(5.49 \pm 0.04)$ algae before deploying the experiment. Sediment organic matter (TOC, TN, C:N) at the end of the experiment (Table 1) did not differ significantly among treatments $(p>0.05)$ or between sediment depths for any of the food variables (i.e. TOC, TN, C:N) (Table 2, Fig. 8).

\subsection{Epifauna}

$N$. oculata enrichment attracted more visitors (178 total ind.) in the first $15 \mathrm{~d}$ after experimental deployment than the other 2 treatments (procedural control: 99; C. calcitrans: 114). Brachyura and Caridea domi-
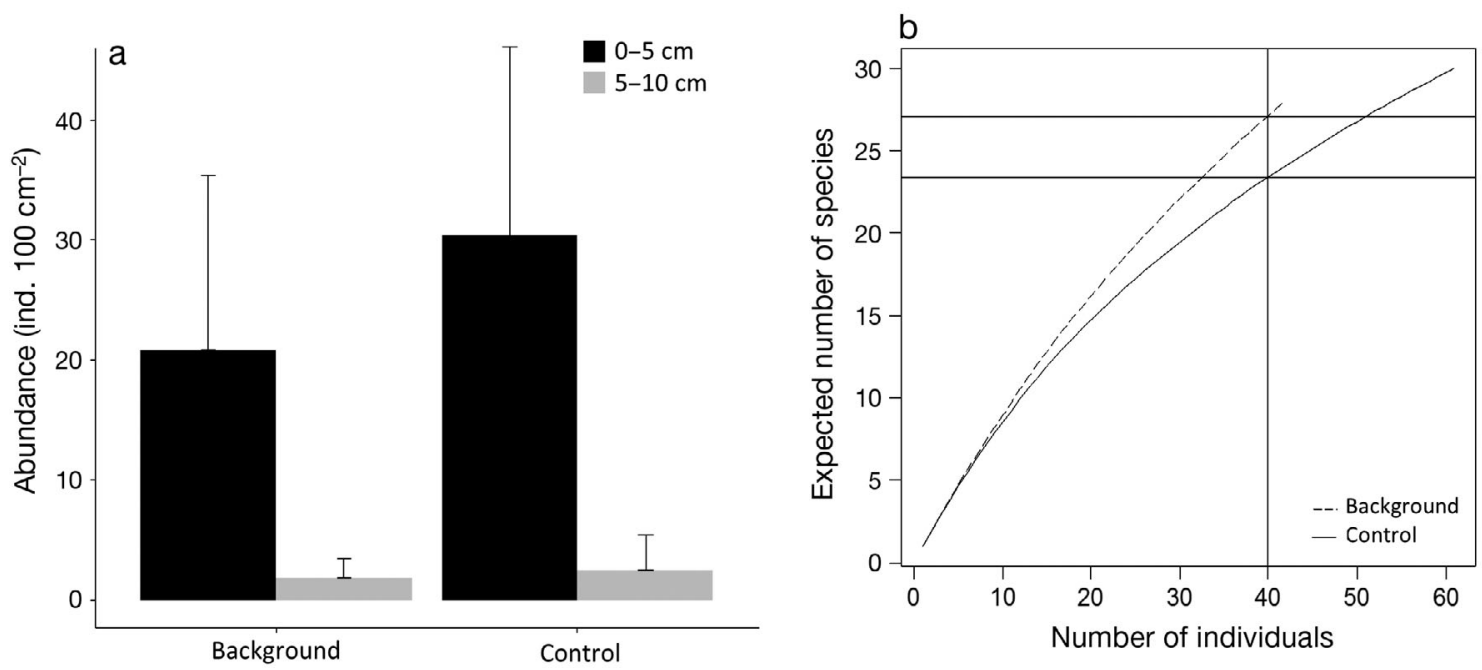

Fig. 6. Effects of cage frames on macroinfaunal communities from Barkley Canyon: (a) total infaunal abundances per treatment and sediment (error bars: $1 \mathrm{SD}$ ); and (b) expected number of species per treatment; lines: number of species at 40 individuals; $\mathrm{n}=6$ for background and control per sediment layer 


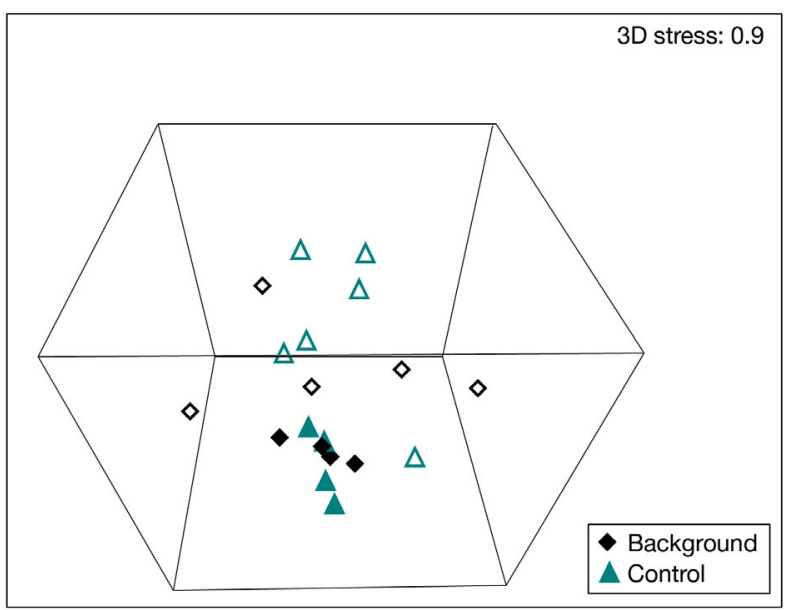

Fig. 7. Non-metric multidimensional scaling (nMDS) based on infaunal response to cage frames used in a food enrichment experiment in Barkley Canyon. Assemblages are based on Bray-Curtis similarity with dummy variable and $\log (x+1)$ transformation. Blank symbols: $0-5 \mathrm{~cm}$ sediment depth layer; filled symbols: 5-10 cm layer; $\mathrm{n}=6$ for background and control per sediment layer

Table 1. Total organic carbon (TOC), Total nitrogen (TN), and C:N ratios from sedimentary organic matter at Barkley Canyon (NE Pacific, $890 \mathrm{~m}$ depth) from procedural control, Chaetoceros calcitrans, and Nannochloropsis oculata treatments at each sediment depth $(0-5$ and $5-10 \mathrm{~cm})$

\begin{tabular}{|lcccc|}
\hline $\begin{array}{l}\text { Experiment } \\
\text { treatment }\end{array}$ & $\begin{array}{c}\text { Sediment } \\
\text { depth }(\mathrm{cm})\end{array}$ & TOC & TN & C:N \\
\hline Procedural control & $0-5$ & $2.7 \pm 0.1$ & $0.3 \pm 0.02$ & $9.1 \pm 0.4$ \\
Procedural control & $5-10$ & $2.6 \pm 0.1$ & $0.3 \pm 0.02$ & $9.3 \pm 0.6$ \\
C. calcitrans & $0-5$ & $2.6 \pm 0.1$ & $0.3 \pm 0.01$ & $9.1 \pm 0.3$ \\
C. calcitrans & $5-10$ & $2.7 \pm 0.1$ & $0.3 \pm 0.01$ & $9.2 \pm 0.2$ \\
N. oculata & $0-5$ & $2.7 \pm 0.1$ & $0.3 \pm 0.01$ & $8.8 \pm 0.1$ \\
N. oculata & $5-10$ & $2.5 \pm 0.1$ & $0.3 \pm 0.01$ & $8.8 \pm 0.1$ \\
\hline
\end{tabular}

Table 2. Results from ANOVA analysis on total nitrogen (TN) and $\mathrm{C}: \mathrm{N}$ ratios from sedimentary organic matter at Barkley Canyon (NE Pacific, $890 \mathrm{~m}$ depth), and Kruskal-Wallis from total organic matter (TOC) between treatments (control, Chaetoceros calcitrans, and Nannochloropsis oculata) and sediment depth (0-5 and 5-10 cm)

\begin{tabular}{|c|c|c|c|c|c|}
\hline $\begin{array}{l}\text { Vari- } \\
\text { able }\end{array}$ & Source & $\mathrm{df}$ & SS & $\begin{array}{c}F \text {-value/ } \\
\chi^{2}\end{array}$ & $\begin{array}{l}\operatorname{Pr}(>F) / \\
\text { p-value }\end{array}$ \\
\hline \multirow[t]{2}{*}{ TOC } & Treatment & 2 & - & 1.76 & 0.415 \\
\hline & Sediment depth & 1 & - & 2.18 & 0.14 \\
\hline \multirow[t]{4}{*}{$\mathrm{TN}$} & Treatment & 2 & 0.00 & 0.29 & 0.749 \\
\hline & Sediment depth & 1 & 0.00 & 2.39 & 0.144 \\
\hline & Treatment: sediment depth & 2 & 0.00 & 0.81 & 0.465 \\
\hline & Residuals & 14 & 0.00 & - & - \\
\hline \multirow[t]{4}{*}{$\mathrm{C}: \mathrm{N}$} & Treatment & 2 & 0.63 & 2.35 & 0.132 \\
\hline & Sediment depth & 1 & 0.05 & 0.39 & 0.541 \\
\hline & Treatment: sediment depth & 2 & 0.06 & 0.25 & 0.785 \\
\hline & Residuals & 14 & 1.90 & - & - \\
\hline
\end{tabular}

nated visitors in all treatments. Although proportions were similar to the procedural control (Fig. 9), Brachyura dominated over Caridea in both algal treatments with a much clearer dominance in $N$. oculata than C. calcitrans treatments (Fig. 9). Finally, we observed that the cage frames played a sheltering and support role for epifauna. We observed brachyurans positioned underneath the cage frame and close to the leg bases, carideans on top of the cage frame, and Munidospis sp. on the legs of the cage frame.

\subsection{Food patch surface area}

Longevity of the 2 different food patches (C. Calcitrans and $N$. oculata) differed by 4 mo (Fig. 10). C. calcitrans disappeared in April 2014 (7 mo after deployment) whereas $N$. oculata disappeared in December 2013 (3.5 mo after deployment). However, the majority of the food patch (>90\%) had vanished in both treatments by the end of October 2013 (i.e.

1.5 mo after deployment). The 2 treatments differed in disturbance frequency. The patch size of C. calcitrans decreased abruptly twice (arrows in Fig. 10), whereas $N$. oculata relative surface area decreased more gradually until mid-October 2013 (arrow in Fig. 10), when surface area briefly increased, and then continued to decline.

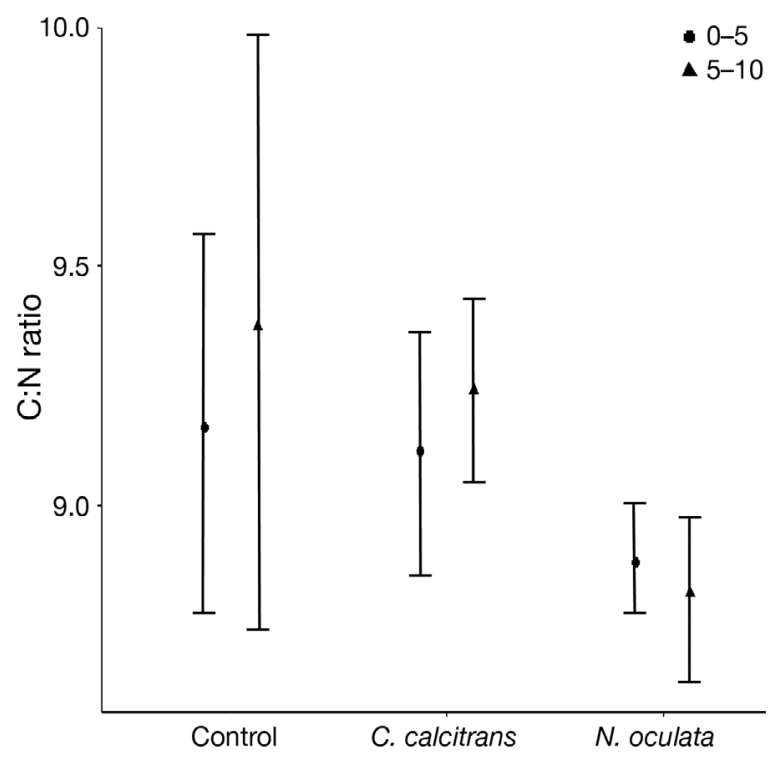

Fig. 8. Mean C:N ratio of sediment organic matter at 3 different treatments and 2 sediment depths ( $0-5$ and $5-10 \mathrm{~cm}$ ) from an enrichment experiment in Barkley Canyon. C. calcitrans: Chaetoceros calcitrans; N. oculata: Nannochloropsis oculata. Error bars: $1 \mathrm{SD} ; \mathrm{n}=3$ for each treatment and sediment depth 


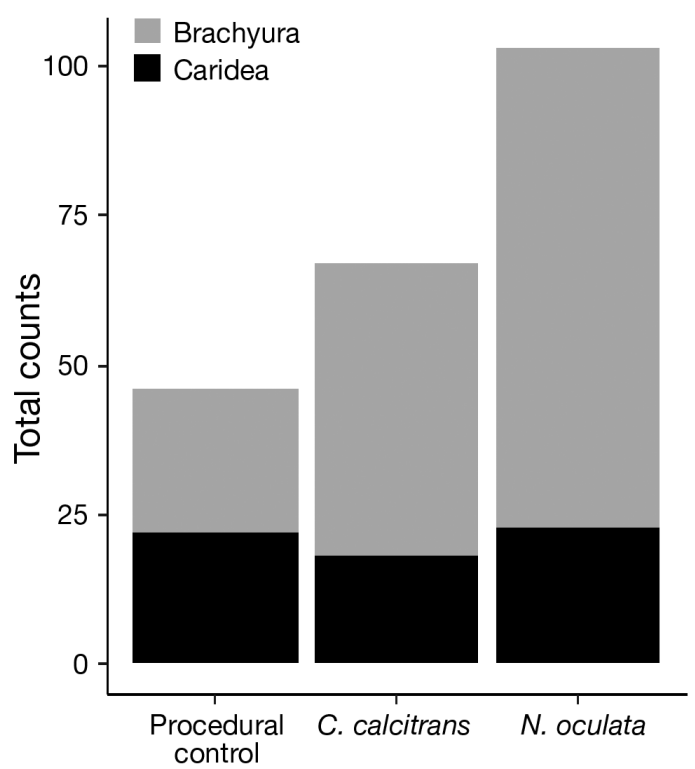

Fig. 9. Total number of counts per treatment of the most common taxa over a period of $15 \mathrm{~d}$ from a food enrichment experiment in Barkley Canyon (890 m depth). C. calcitrans: Chaetoceros calcitrans; N. oculata: Nannochloropsis oculata. We only included in this graph annotations from videos where the analysis for the 3 treatments was possible $(\mathrm{n}=54)$

\section{DISCUSSION}

\subsection{Infaunal community structure}

Food enrichment experiments often compare very distinct food qualities (e.g. terrestrial vs. marine organic matter, macroalgae vs. microalgae) to ensure a strong signal in the response variable of interest.
Few studies base their in situ food experiments on different phytoplankton species (Ingels et al. 2011, Jeffreys et al. 2013, Mäkelä et al. 2017). A clear signal in these kinds of experiments requires strong selective feeding. For example, nematodes from polar regions ingest bacterial carbon more rapidly than diatom carbon, thus indicating a food preference (Ingels et al. 2010). Our experiment tested more subtle food preference (i.e. between algal classes) than most experiments.

Deeper layers of sediments are usually disconnected from ongoing processes at the sedimentwater interface. Sediments often become anoxic below the top few $\mathrm{mm}$ to $\mathrm{cm}$, confining the vast majority of organisms to sediment surface layers (Snelgrove 1999). Even so, several processes can connect surface and subsurface sediments, for example, through bioturbation. Biological activity can mix the surface layer of deep-sea sediments to depths of $\sim 10 \mathrm{~cm}$ (Guinasso \& Schink 1975). For example, maldanid polychaetes can transport freshly deposited organic matter to $10 \mathrm{~cm}$ deep within the sediment in short time periods (1.5 di Levin et al. 1997). This transport of added food particles from surface to deep sediments could influence community structure at those sediment depths.

We observed differences, although not significant, in overall species distributions among treatments in surface sediment layers, which differed slightly in $\mathrm{C}: \mathrm{N}$ ratios at the end of the experiment. Our analyses identified Aricidea sp. juveniles as distinctive within Nannochloropsis oculata enrichment patches, suggesting a degree of selectivity in these juveniles.
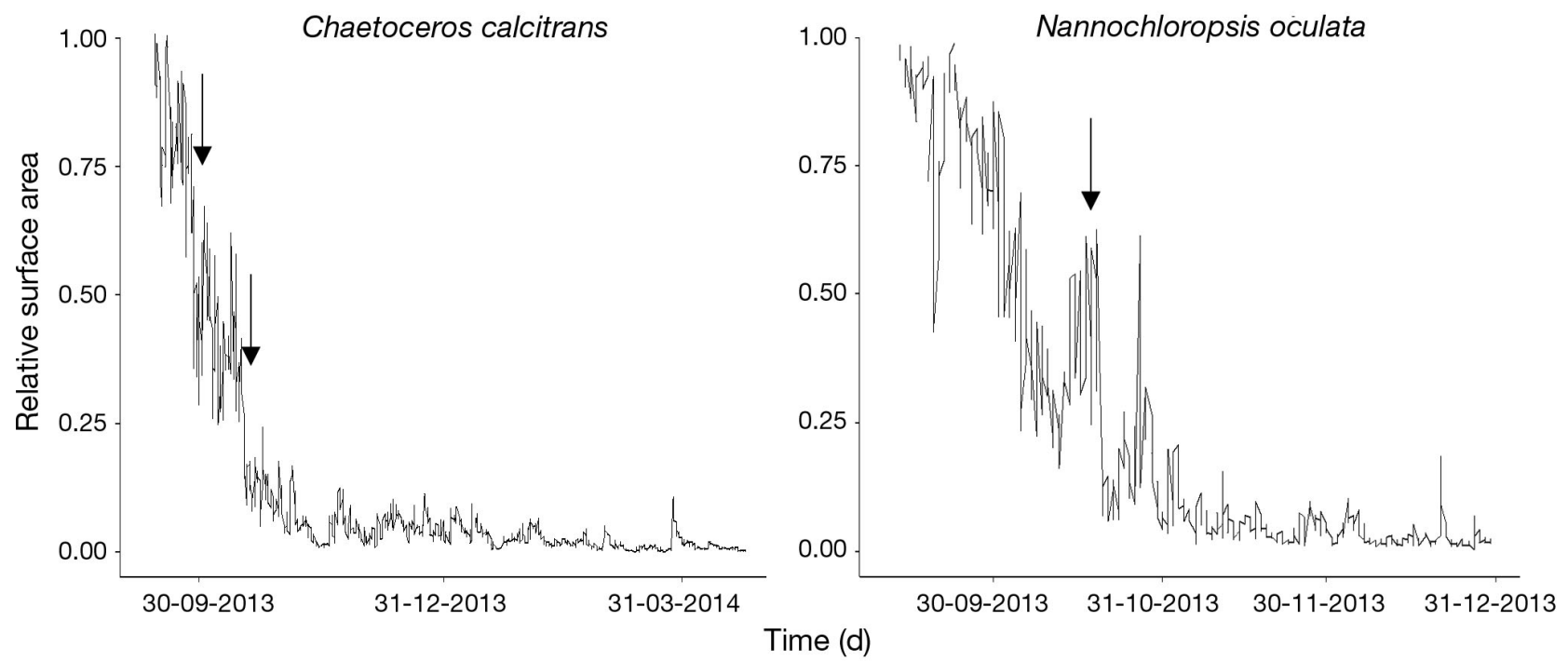

Fig. 10. Relative surface area of food in 2 different food patches, Chaetoceros calcitrans and Nannochloropsis oculata, at Barkley Canyon (890 m depth) over time. Arrows: episodic events with sudden increases or decreases in relative surface area covered 
Feeding modes of paraonid polychaetes vary greatly, but selectivity has been observed in some species (Sweetman \& Witte 2008, Jumars et al. 2015). Even though we could not prove the inert effect of kaolin clay and fluorescent dye on benthic macroinfauna, we nonetheless demonstrated that observed differences in community response were not simply an artefact of the cage frames we deployed to protect the enrichment patches from sablefish disturbance.

Pulses of organic matter to the sea floor can influence ecosystem functioning (e.g. carbon and nitrogen mineralization, biological traits) and/or community structure, observed through experimental setups (Levin et al. 1999, Gallmetzer et al. 2005, Quijón et al. 2008, Mayor et al. 2012) or through field observations (Amaro et al. 2015, Campanyà-Llovet et al. 2018). We only found weak differences in the response of functional groups to food pulses differing in quality (i.e. different algal classes). Juveniles of some species contributed to separation of algal treatments from the procedural control in ordination space, pointing to selection of organic patches by some organisms. Motility and feeding mode are linked (Jumars et al. 2015): the degree of motility of an organism depends on its distance from, and longevity of, resource availability (Grünbaum 2002). For example, there are no completely sessile macrophagous feeders (Jumars et al. 2015) because they must search for large food items (e.g. macroalgae or prey). Even so, we found no treatment separation based on organism motility. Among different feeding structures (i.e. palps, tentacles, and pharynx), tentacles often suggest selective feeding, whereas an eversible pharynx often suggests generalist feeding (Jumars et al. 2015); species with tentacles as feeding structures helped to separate, although not significantly, faunas in sediments enriched with Chaetoceros calcitrans from those in control sediments and those enriched with $N$. oculata. Differences in functional groups could have profound impacts on nutrient cycling in the deep ocean, and on global estimates of carbon remineralization and burial (Snelgrove et al. 2018).

Food quality can influence benthic community and food-web structure (Wieking \& Kröncke 2005, Campanyà-Llovet et al. 2017). C:N ratios and TN provide a first insight into the nutritional value of a food source because protein formation requires nitrogen, which limits primary production in many marine ecosystems (Howarth 1988). In fact, the lower (although not significant) $\mathrm{C}: \mathrm{N}$ ratios from sediments enriched with $N$. oculata in our experiment coincided with observed structural changes in the infaunal community. Preferential consumption of organic nitrogen by benthic fauna (Evrard et al. 2010), which is controlled by organismal $\mathrm{C}: \mathrm{N}$ budgets and therefore demands (Hunter et al. 2012, Jeffreys et al. 2013), demonstrates the relevance of C:N as a metric of food quality for benthic organisms. Low carbon uptake of terrestrial organic matter by benthic macrofauna from Whittard Canyon, NE Atlantic, was most likely related to high $\mathrm{C}: \mathrm{N}$ ratios, and therefore, nitrogen limitation of the food source (Hunter et al. 2013).

PUFAs, essential fatty acids, and some sterols, which differ among algal species (Volkman et al. 1981, Banerjee et al. 2011, Parrish et al. 2015, Pethybridge et al. 2015), are indispensable to most cultured marine organisms (Müller-Navarra 2008, Glencross 2009). Despite new insights (Kabeya et al. 2018) on the genetics involved in synthesis of essential fatty acids (e.g. 20:503 [EPA; eicosapentaenoic acid],

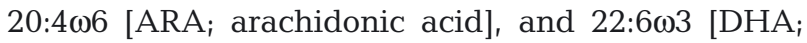
docosapentaenoic acid]), most benthic species cannot synthesize these acids de novo even though they play an important role in metabolic function, reproductive output, and provisioning membrane structure/function (Parrish. 2009). N. oculata, like all Eustigmatophiceae, have high proportions of EPA and ARA, in contrast to a high proportion of EPA and the presence of ARA and DHA in diatoms (Hodgson et al. 1991, Brown et al. 1997). Nannochloropsis spp. also differ from other microalgae because they build up high concentrations of a range of pigments such as astaxanthin, zeaxanthin, and canthaxanthin (Lubián et al. 2000). These differences in food quality may vary in degree depending on culturing conditions (Cheirsilp \& Torpee 2012); however, in broad general terms they remain valid, and may explain structural changes observed in the infaunal community in our experiment.

Only selective feeding could explain differences in species composition of the infaunal community among food treatments. Some polychaete species selectively feed on apparently homogeneous detrital material (Self \& Jumars 1988). Tentaculate deposit feeders (such as spionids, and ampharetid polychaetes observed in our study) can select for specific (generally small) particle sizes (Jumars et al. 1982). Our results showed non-significant differences among tentaculate polychaetes, suggesting no selectivity among food treatments from our experiment despite the selective feeding capabilities of some of these organisms Deposit feeder particle selectivity may be largely passive and mechanical: the surface texture of natural grains increases probability of selection by tentacles, and bacteria-coated grains appear to be picked up preferentially because of adhesion to the bacterial coating (Guieb et al. 2004). Tentaculate feeders can select for particles using muscles, cilia, 
and mucus with different adhesive properties that enhance the proportion of protein in ingested food (Lopez \& Levinton 1987). Selective feeding also occurs in suspension- and deposit-feeding bivalves (such as thyasirid bivalves observed in our study), with species-specific processes based on physical and chemical characteristics of the particles (Ward \& Shumway 2004).

Previous enrichment experiments in the field have reported responses by colonizers after the addition of organic matter into the sediments. Total abundance and biodiversity changed among trays enriched with different food sources (i.e. diatom vs. brown macroalgae) and degradation state (Snelgrove et al. 1992, 1996). Although our food patches occupied $\sim 120 \mathrm{~cm}^{2}$, they fall within the areal range $\left(50-1750 \mathrm{~cm}^{2}\right)$ in which different colonization modes generally balance (i.e. settlement from water column vs. reproduction by species with benthic development vs. immigration of juveniles from the surrounding sediments; Smith \& Brumsickle 1989). Studies examining trophic pathways through food enrichments have demonstrated differential uptake of pulses of organic matter by different taxa (Witte et al. 2003, Hunter et al. 2013, Jeffreys et al. 2013), and even among polychaete families (Sweetman \& Witte 2008). These differences suggest taxon-dependent efficiency in carbon uptake, and could explain increases in abundances of some taxa, leading to community structure changes. Whereas experiments with enriched trays evaluate recruitment, 'pulse-chase' experiments focus on which food resource particular organisms select and ingest more efficiently; a community experiment such as ours considers both, and determines changes in community structure.

We expected a rapid increase in the numbers of individuals in algal patches shortly after the experiment deployments (first few days or weeks), given the rapid uptake of organic matter by benthic macroinfauna observed in enrichment experiments using ${ }^{13} \mathrm{C}$-labeled algae (Levin et al. 1999, Witte et al. 2003). However, because our experiment ran for $8 \mathrm{mo}$, any initial attraction to a food pulse had presumably attenuated by the time we recovered the experiment. Based on the longevity of our patches (see Section 4.3. below), ideally we would have resampled the experiment within 1 mo of deployment to detect maximum numbers of larval or juvenile colonizers and/or organisms migrating to preferred food patches, and associated reworking and uptake of the introduced organic carbon. The high organic matter content at that station compared to other canyon locations (Campanyà-Llovet et al. 2018) may dampen the need for niche speciation, and therefore, selective feeding and macrofaunal response. Short pulses of chl a arriving to the benthos $600 \mathrm{~m}$ away from the experimental area, but at the same depth $(\sim 890 \mathrm{~m})$, during the winter months (Thomsen et al. 2017) may have also dampened any clear responses from our experiment, which ran from September to May. Furthermore, the influence of an environmental stressor such as an $\mathrm{OMZ}$, which can alter the processing of organic matter (Woulds et al. 2007), may obscure the effects of food quality on benthic communities (Campanyà-Llovet et al. 2017). The lack of experimentation outside the OMZ precludes a discussion on the direct effect of oxygen on our experiment.

\subsection{Epifaunal number of visits to patch}

Highly mobile and visible crustaceans dominated the visitors in the area: Brachyura, Caridea, Munidopsis sp., and Paguroidea were all reported previously in the same season (fall) in Barkley Canyon (Juniper et al. 2013). Other studies in Barkley Canyon at the same depth but in a chemosynthetic environment reinforce the presence of small crabs and grooved tanner crabs in September (Doya et al. 2017), although not in high abundances. The observed differences may result from different habitat type (chemosynthetic vs. non-chemosynthetic) or the use of different camera systems (mobile camera vs. fixed; Doya et al. 2017). Benthic and mobile epifauna can aggregate in areas with enriched organic matter content based on their feeding preferences (Amaro et al. 2015); however, Chionoecetes opilio, a congener of the grooved tanner crab Chionoecetes tanneri commonly found at our sampling station (Juniper et al. 2013), is a carnivore and a scavenger that feeds on bivalves, polychaetes, amphipods, and other crustaceans (Divine et al. 2017); unfortunately, we lack data on $C$. tanneri feeding preferences. Although species of scavengers, such as certain macrourid fishes and crustaceans, occasionally feed on pulses of phytodetritus (Jeffreys et al. 2011), we suggest that increased brachyurans in the algal treatments in the first $2 \mathrm{wk}$ following experiment deployment resulted from increased prey abundances within the sediment, rather than attraction of Brachyura to the actual food treatment, because we did not observe such feeding behaviour. We also observed brachyurans feeding on larger food falls (i.e. gelatinous material) outside the cage frames, adding scavenging to a predatory diet (N. Campanyà-Llovet pers. obs.). The 
irregular terrain surrounding the $N$. oculata enrichment patch compared to the C. calcitrans or procedural control patches may have played a role. Again, the absence of imagery from other experimental replicates precludes definitive conclusions on differences in patch visitors.

The higher counts of mega-epifauna during the first $2 \mathrm{wk}$ after the deployment of the experiment suggest increased predatory pressure in the sediments enriched with $N$. oculata. The deeper sediment layers occasionally provide refuge from predators to infaunal species. Total abundances in sediment patches enriched with $N$. oculata were slightly lower than in the procedural control and C. calcitrans surface sediment layers, but slightly higher in the deeper sediment layer. These results, although not statistically significant, support the idea of a predatory refuge in deeper sediments.

\subsection{Patch disappearance}

The organic matter we added to Barkley Canyon ( $890 \mathrm{~m}$ depth) was likely remineralized and/or buried. Most organic matter produced in the photic zone and deposited onto the sediment surface is recycled and remineralized, with burial of a small proportion (Rullkötter. 2006). Deep-sea benthic organisms begin to ingest organic matter only a few days after it arrives (Witte et al. 2003). The organic matter reworked by benthic organisms enters each size compartment (i.e. bacteria, meiofauna, macrofauna, megafauna) in different proportions, which varies with ecosystem (Smith et al. 2008). Given the negligible effect of bottom currents on patch movement at our site (based on our preliminary experiments), our results suggest that benthic organisms (i.e. bacteria, meiofauna, macrofauna, and megafauna) in Barkley Canyon at $890 \mathrm{~m}$ depth reworked $~ 90 \%$ of $88.2 \mathrm{mg}$ of carbon in $~ 1.5$ mo. Even so, we found differences in the removal of the visible food patch with time between the 2 algal treatments. First, the organic matter remaining after $\sim 1.5$ mo persisted longer in $C$. calcitrans (an additional $5.5 \mathrm{mo}$ ) than in $N$. oculata (an additional $2 \mathrm{mo}$ ). Second, episodic events varied among treatments. Two episodic events substantially reduced C. calcitrans patch size, suggesting a sudden uptake or disturbance by a large organism, as reported in other experiments (Jeffreys et al. 2011). At the same time, the N. oculata patch actually increased in surface area, likely as a result of sediment movement and reworking that flattened the food patch, thereby increasing its surface area. As noted earlier, although these results offer valuable information on patch longevity at bathyal depths, lack of replication limits our conclusions.

\section{CONCLUSIONS}

Food supply can depend on environmental variation in the form of increases/decreases in POC flux (and therefore amounts of food) and/or in the form of changes in organic matter biochemistry (and thus, food quality). In this study, we showed that differences in food quality, at the algal class level, can modify benthic infaunal community structure and attract different epifaunal species, although we recommend a shorter time-frame (e.g. $1 \mathrm{mo}$ ) for this type of experiment to achieve more conclusive results. These kinds of integrative studies are useful in understanding interactions among size compartments (e.g. macroinfauna and mega-epifauna), in that the Nannochloropsis oculata food patch received more epifaunal visitors. However, more robust conclusions require shorter experiments and higher numbers of replicates.

These findings have ramifications for predicting climate change impacts on the benthos. The sensitivity of planktonic species to temperature change can lead to phenological alterations and biogeographic shifts at the species level, resulting in a trophic mismatch within the food web, or abrupt shifts in planktonic community structure and therefore changes in the biochemistry of the flux of organic matter to the benthos. These changes in species composition can influence the biochemistry of this flux (i.e. algal composition).

Acknowledgements. We thank Dr. Ursula Witte for loaning the spreaders used to conduct the experiment. We thank Ocean Networks Canada and the Schmidt Ocean Institute for sampling opportunities and the time allocated to the deployment and recovery of the experiment in Barkley Canyon, the officers and crews of the RV 'Falkor' and the CSSF ROPOS team for their assistance in sample collection. We thank chief scientist Dr. Kim Juniper for sampling opportunities and Ocean Networks Canada and Karen Douglas for permission and assistance in using bathymetric maps of Barkley Canyon. We thank Alison Pye for help on C:N analysis. We also thank Adena Peters for her help in analysing the images of surface area of the algal patches. Drs. A. Metaxas, A. Mercier, and C. Parrish provided helpful comments on an earlier version of the manuscript. We also thank an anonymous reviewer, Dr. J. Aguzzi, and Dr. M. Solan for their useful insight on the manuscript. This work was supported by NSERC Discovery Grants to P.V.R.S. and a fellowship to N.C.L. from Memorial University School of Graduate Studies. 


\section{LITERATURE CITED}

Amaro T, de Stigter H, Lavaleye M, Duineveld G (2015) Organic matter enrichment in the Whittard Channel; its origin and possible effects on benthic megafauna. Deep Sea Res I 102:90-100

Anderson M, Gorley R, Clarke K (2008) PERMANOVA+ for PRIMER: guide to software and statistical methods. PRIMER-E, Plymouth

Azovsky AI, Saburova MA, Chertoprood ES, Polikarpov IG (2005) Selective feeding of littoral harpacticoids on diatom algae: hungry gourmands? Mar Biol 148:327-337

Banerjee S, Hew WE, Khatoon H, Shariff M, Yusoff FM (2011) Growth and proximate composition of tropical marine Chaetoceros calcitrans and Nannochloropsis oculata cultured outdoors and under laboratory conditions. Afr J Biotechnol 10:1375-1383

Barnard JL, Karaman GS (1991) The families and genera of marine gammaridean Amphipoda (except marine gammaroids). Rec Aust Mus 13(Suppl):1-866

Beaulieu SE (2002) Accumulation and fate of phytodetritus on the sea floor. Oceanogr Mar Biol Annu Rev 40:171-232

Billett DSM, Bett BJ, Reid WDK, Boorman B, Priede IG (2010) Long-term change in the abyssal NE Atlantic: the 'Amperima Event' revisited. Deep Sea Res II 57: 1406-1417

Blake JA, Hilbig B, Scott PH (eds) (1996a) Taxonomic atlas of the benthic fauna of the Santa Maria Basin and western Santa Barbara Channel, Vol 4. The Annelida, Part 1: Oligochaeta and Polychaeta: Phyllodocida (Phyllodocidae to Paralacydoniidae). Santa Barbara Museum of Natural History, Santa Barbara, CA

Blake JA, Hilbig B, Scott PH (eds) (1996b) Taxonomic atlas of the benthic fauna of the Santa Maria Basin and western Santa Barbara Channel, Vol 6. The Annelida, Part 3: Polychaeta: Orbiniidae to Cossuridae. Santa Barbara Museum of Natural History, Santa Barbara, CA

Blake JA, Hilbig B, Scott PH (eds) (1996c) Taxonomic atlas of the benthic fauna of the Santa Maria Basin and western Santa Barbara Channel, Vol 7. The Annelida, Part 4: Polychaeta: Flabelligeridae to Ampharetidae. Santa Barbara Museum of Natural History, Santa Barbara, CA

Boon AR, Duineveld GCA (2012) Phytopigments and fatty acids in the gut of the deposit-feeding heart urchin Echinocardium cordatum in the southern North Sea: selective feeding and its contribution to the benthic carbon budget. J Sea Res 67:77-84

Bousfield EL (1973) Shallow-water gammaridean Amphipoda of New England. Cornell University Press, Ithaca, NY

Brown MR, Jeffrey SW, Volkman JK, Dunstan GA (1997) Nutritional properties of microalgae for mariculture. Aquaculture 151:315-331

Campanyà-Llovet N, Snelgrove PVR, Parrish CC (2017) Rethinking the importance of food quality in marine benthic food webs. Prog Oceanogr 156:240-251

Campanyà-Llovet N, Snelgrove PVR, De Leo FC (2018) Food quantity and quality in Barkley Canyon (NE Pacific) and its influence on macroinfaunal community structure. Prog Oceanogr 169:106-119

Cheirsilp B, Torpee S (2012) Enhanced growth and lipid production of microalgae under mixotrophic culture condition: effect of light intensity, glucose concentration and fed-batch cultivation. Bioresour Technol 110: $510-516$
Clarke K, Gorley R (2006) PRIMER v6: user manual/tutorial. PRIMER-E, Plymouth

Cognie B, Barillé L, Rincé Y (2001) Selective feeding of the oyster Crassostrea gigas fed on a natural microphytobenthos assemblage. Estuaries 24:126-134

Cohen Z (ed) (1999) Chemicals from microalgae. Taylor \& Francis, London

Dauwe B, Herman PMJ, Heip CHR (1998) Community structure and bioturbation potential of macrofauna at four North Sea stations with contrasting food supply. Mar Ecol Prog Ser 173:67-83

Defossez JM, Hawkins AJS (1997) Selective feeding in shellfish: size-dependent rejection of large particles within pseudofaeces from Mytilus edulis, Ruditapes philippinarum and Tapes decussatus. Mar Biol 129:139-147

Divine LM, Bluhm BA, Mueter FJ, Iken K (2017) Diet analysis of Alaska Arctic snow crabs (Chionoecetes opilio) using stomach contents and $\delta^{13} \mathrm{C}$ and $\delta^{15} \mathrm{~N}$ stable isotopes. Deep Sea Res II 135:124-136

Domke L, Lacharité M, Metaxas A, Matabos M (2017) Influence of an oxygen minimum zone and macroalgal enrichment on benthic megafaunal community composition in a NE Pacific submarine canyon. Mar Ecol 38: e12481

Doya C, Chatzievangelou D, Bahamon N, Purser A and others (2017) Seasonal monitoring of deep-sea cold seep benthic communities using an internet operated vehicle (IOV). PLOS ONE 12:e0176917

Estifanos TK, Traunspurger W, Peters L (2013) Selective feeding in nematodes: a stable isotope analysis of bacteria and algae as food sources for free-living nematodes. Nematology 15:1-13

Evrard V, Soetaert K, Heip CHR, Huettel M, Xenopoulos MA, Middelburg JJ (2010) Carbon and nitrogen flows through the benthic food web of a photic subtidal sandy sediment. Mar Ecol Prog Ser 416:1-16

Fornes WL, DeMaster DJ, Levin LA, Blair NE (1999) Bioturbation and particle transport in Carolina slope sediments: a radiochemical approach. J Mar Res 57:335-355

Galéron J, Sibuet M, Vanreusel A, Mackenzie K, Gooday AJ, Dinet A, Wolff GA (2001) Temporal patterns among meiofauna and macrofauna taxa related to changes in sediment geochemistry at an abyssal NE Atlantic site. Prog Oceanogr 50:303-324

Gallmetzer I, Pflugfelder B, Zekely J, Ott JA (2005) Macrofauna diversity in Posidonia oceanica detritus: distribution and diversity of mobile macrofauna in shallow sublittoral accumulations of Posidonia oceanica detritus. Mar Biol 147:517-523

Ginger ML, Billett DSM, Mackenzie KL, Kiriakoulakis K and others (2001) Organic matter assimilation and selective feeding by holothurians in the deep sea: some observations and comments. Prog Oceanogr 50:407-421

Glencross BD (2009) Exploring the nutritional demand for essential fatty acids by aquaculture species. Rev Aquacult 1:71-124

Grassle JF, Morse-Porteous LS (1987) Macrofaunal colonization of disturbed deep-sea environments and the structure of deep-sea benthic communities. Deep Sea Res A Oceanogr Res Pap 34:1911-1950

Grassle JF, Sanders HL (1973) Life histories and role of disturbance. Deep-Sea Res 20:643-659

Grünbaum D (2002) Predicting availability to consumers of spatially and temporally variable resources. Hydrobiologia 480:175-191 
Guieb RA, Jumars PA, Self RFL (2004) Adhesive-based selection by a tentacle-feeding polychaete for particle size, shape and bacterial coating in silt and sand. J Mar Res 62:260-281

Guinasso NL Jr, Schink DR (1975) Quantitative estimates of biological mixing rates in abyssal sediments. J Geophys Res 80:3032-3043

Hartman O (1968) Atlas of the errantiate polychaetous annelids from California. Allan Hancock Foundation, Los Angeles, CA

Hartman O (1969) Atlas of the sedentariate polychaetous annelids from California. Allan Hancock Foundation, Los Angeles, CA

Hodgson PA, Henderson RJ, Sargent JR, Leftley JW (1991) Patterns of variation in the lipid class and fatty acid composition of Nannochloropsis oculata (Eustigmatophyceae) during batch culture. J Appl Phycol 3:169-181

Howarth RW (1988) Nutrient limitation of net primary production in marine ecosystems. Annu Rev Ecol Syst 19: 89-110

Hunter WR, Levin LA, Kitazato H, Witte U (2012) Macrobenthic assemblage structure and organismal stoichiometry control faunal processing of particulate organic carbon and nitrogen in oxygen minimum zone sediments. Biogeosciences 9:993-1006

Hunter WR, Jamieson A, Huvenne VAI, Witte U (2013) Sediment community responses to marine vs. terrigenous organic matter in a submarine canyon. Biogeosciences 10:67-80

Ingels J, Van den Driessche P, De Mesel I, Vanhove S, Moens T, Vanreusel A (2010) Preferred use of bacteria over phytoplankton by deep-sea nematodes in polar regions. Mar Ecol Prog Ser 406:121-133

Ingels J, Billett DSM, Van Gaever S, Vanreusel A (2011) An insight into the feeding ecology of deep-sea canyon nematodes - results from field observations and the first in-situ ${ }^{13} \mathrm{C}$ feeding experiment in the Nazaré Canyon. J Exp Mar Biol Ecol 396:185-193

Jeffreys RM, Lavaleye MSS, Bergman MJN, Duineveld GCA, Witbaard R (2011) Do abyssal scavengers use phytodetritus as a food resource? Video and biochemical evidence from the Atlantic and Mediterranean. Deep Sea Res I 58:415-428

Jeffreys RM, Burke C, Jamieson AJ, Narayanaswamy BE, Ruhl HA, Smith KL Jr, Witte U (2013) Feeding preferences of abyssal macrofauna inferred from in situ pulse chase experiments. PLOS ONE 8:e80510

Jumars PA, Self RFL, Nowell ARM (1982) Mechanics of particle selection by tentaculate deposit-feeders. J Exp Mar Biol Ecol 64:47-70

Jumars PA, Dorgan KM, Lindsay SM (2015) Diet of worms emended: an update of polychaete feeding guilds. Annu Rev Mar Sci 7:497-520

Juniper SK, Matabos M, Mihály S, Ajayamohan RS, Gervais F, Bui AOV (2013) A year in Barkley Canyon: a timeseries observatory study of mid-slope benthos and habitat dynamics using the NEPTUNE Canada network. Deep Sea Res II 92:114-123

Kabeya N, Fonseca MM, Ferrier DEK, Navarro JC and others (2018) Genes for de novo biosynthesis of omega-3 polyunsaturated fatty acids are widespread in animals. Sci Adv 4:eaar6849

Keeling RF, Körtzinger A, Gruber N (2010) Ocean deoxygenation in a warming world. Annu Rev Mar Sci 2: 199-229
Kelaher BP, Levinton JS (2003) Variation in detrital enrichment causes spatio- temporal variation in soft-sediment assemblages. Mar Ecol Prog Ser 261:85-97

Levin L, Blair N, DeMaster D, Plaia G, Fornes W, Martin C, Thomas C (1997) Rapid subduction of organic matter by maldanid polychaetes on the North Carolina slope. J Mar Res 55:595-611

Levin LA, Blair NE, Martin CM, DeMaster DJ, Plaia G, Thomas CJ (1999) Macrofaunal processing of phytodetritus at two sites on the Carolina margin: in situ experiments using ${ }^{13} \mathrm{C}$-labeled diatoms. Mar Ecol Prog Ser 182: $37-54$

Levin LA, Etter RJ, Rex MA, Gooday AJ and others (2001) Environmental influences on regional deep-sea species diversity. Annu Rev Ecol Syst 32:51-93

Levin LA, Ziebis W, Mendoza GF, Growney VA and others (2003) Spatial heterogeneity of macrofauna at northern California methane seeps: influence of sulfide concentration and fluid flow. Mar Ecol Prog Ser 265:123-139

Liu J, Song Y, Qiu W (2017) Oleaginous microalgae Nannochloropsis as a new model for biofuel production: review \& analysis. Renew Sustain Energy Rev 72:154-162

Lopez GR, Levinton JS (1987) Ecology of deposit-feeding animals in marine sediments. Q Rev Biol 62:235-260

Loret P, Pastoureaud A, Bacher C, Delesalle B (2000) Phytoplankton composition and selective feeding of the pearl oyster Pinctada margaritifera in the Takapoto lagoon (Tuamotu Archipelago, French Polynesia): in situ study using optical microscopy and HPLC pigment analysis. Mar Ecol Prog Ser 199:55-67

Lubián LM, Montero O, Moreno-Garrido I, Huertas IE, Sobrino C, González-del Valle M, Parés G (2000) Nannochloropsis (Eustigmatophyceae) as source of commercially valuable pigments. J Appl Phycol 12:249-255

Mäkelä A, Witte U, Archambault P (2017) Ice algae versus phytoplankton: resource utilization by Arctic deep sea macroinfauna revealed through isotope labelling experiments. Mar Ecol Prog Ser 572:1-18

Mayor DJ, Thornton B, Hay S, Zuur AF, Nicol GW, McWilliam JM, Witte UFM (2012) Resource quality affects carbon cycling in deep-sea sediments. ISME J 6: 1740-1748

Müller-Navarra DC (2008) Food web paradigms: the biochemical view on trophic interactions. Int Rev Hydrobiol 93:489-505

Neto RR, Wolff GA, Billett DSM, Mackenzie KL, Thompson A (2006) The influence of changing food supply on the lipid biochemistry of deep-sea holothurians. Deep Sea Res I 53:516-527

Parrish CC (2009) Essential fatty acids in aquatic food webs. In: Arts MT, Brett MT, Kainz MJ (eds) Lipids in aquatic ecosystems. Springer, New York, NY, p 309-326

Parrish CC (2013) Lipids in marine ecosystems. ISRN Oceanogr 2013:604045

Parrish CC, Pethybridge H, Young JW, Nichols PD (2015) Spatial variation in fatty acid trophic markers in albacore tuna from the southwestern Pacific Ocean - a potential 'tropicalization' signal. Deep Sea Res II 113:199-207

Pethybridge HR, Parrish CC, Morrongiello J, Young JW, Farley JH, Gunasekera RM, Nichols PD (2015) Spatial patterns and temperature predictions of tuna fatty acids: tracing essential nutrients and changes in primary producers. PLOS ONE 10:e0131598

Pusceddu A, Bianchelli S, Gambi C, Danovaro R (2011) Assessment of benthic trophic status of marine coastal 
ecosystems: significance of meiofaunal rare taxa. Estuar Coast Shelf Sci 93:420-430

Quijón PA, Kelly MC, Snelgrove PVR (2008) The role of sinking phytodetritus in structuring shallow-water benthic communities. J Exp Mar Biol Ecol 366:134-145

Reuscher M, Fiege D, Wehe T (2009) Four new species of Ampharetidae (Annelida: Polychaeta) from Pacific hot vents and cold seeps, with a key and synoptic table of characters for all genera. Zootaxa 2191:1-40

Rodriguez P, Martinez-Madrid M, Arrate JA, Navarro E (2001) Selective feeding by the aquatic oligochaete Tubifex tubifex (Tubificidae, Clitellata). Hydrobiologia 463:133-140

Roy S, Llewellyn CA, Egeland ES, Johnsen G (2011) Phytoplankton pigments: characterization, chemotaxonomy and applications in oceanography. Cambridge University Press, New York, NY

Rullkötter J (2006) Organic matter: the driving force for early diagenesis. In: Schultz HD, Zabel M (eds) Marine geochemistry. Springer, Berlin, p 125-168

Self RFL, Jumars PA (1988) Cross-phyletic patterns of particle selection by deposit feeders. J Mar Res 46:119-143

Smith CR, Brumsickle SJ (1989) The effects of patch size and substrate isolation on colonization modes and rates in an intertidal sediment. Limnol Oceanogr 34:1263-1277

Smith CR, De Leo FC, Bernardino AF, Sweetman AK, Arbizu PM (2008) Abyssal food limitation, ecosystem structure and climate change. Trends Ecol Evol 23:518-528

Snelgrove PVR (1999) Getting to the bottom of marine biodiversity: sedimentary habitats: ocean bottoms are the most widespread habitat on earth and support high biodiversity and key ecosystem services. Bioscience 49: 129-138

Snelgrove PVR, Smith CR (2002) A riot of species in an environmental calm: the paradox of the species-rich deepsea floor. Oceanogr Mar Biol Annu Rev 40:311-342

Snelgrove PVR, Grassle JF, Petrecca RF (1992) The role of food patches in maintaining high deep-sea diversity: field experiments with hydrodynamically unbiased colonization trays. Limnol Oceanogr 37:1543-1550

Snelgrove PVR, Grassle JF, Petrecca RF (1994) Macrofaunal response to artificial enrichments and depressions in a deep-sea habitat. J Mar Res 52:345-369

Snelgrove PVR, Grassle JF, Petrecca RF (1996) Experimental evidence for aging food patches as a factor contributing to high deep-sea macrofaunal diversity. Limnol Oceanogr 41:605-614

Snelgrove PVR, Soetaert K, Solan M, Thrush S, and others (2018) Contrasting biogeochemical and biological estimates of carbon turnover on the global seafloor. Trends Ecol Evol 33:96-105

Sweetman AK, Witte U (2008) Macrofaunal response to phytodetritus in a bathyal Norwegian fjord. Deep Sea Res I 55:1503-1514

Editorial responsibility: Martin Solan, Southampton, UK
Sweetman AK, Thurber AR, Smith CR, Levin LA and others (2017) Major impacts of climate change on deep-sea benthic ecosystems. Elem Sci Anth 5:4

Thomsen L, Barnes C, Best M, Chapman R, Pirenne B, Thomson R, Vogt J (2012) Ocean circulation promotes methane release from gas hydrate outcrops at the NEPTUNE Canada Barkley Canyon node. Geophys Res Lett 39:L16605

Thomsen L, Aguzzi J, Costa C, De Leo F, Ogston A, Purser A (2017) The oceanic biological pump: rapid carbon transfer to the deep sea during winter. Sci Rep 7:10763

Tsushlma M, Kawakami T, Mine M, Matsuno T (1997) The role of carotenoids in the development of the sea urchin Pseudocentrotus depressus. Invertebr Reprod Dev 32: 149-153

Volkman JK, Smith DJ, Eglinton G, Forsberg TEV, Corner EDS (1981) Sterol and fatty acid composition of four marine haptophycean algae. J Mar Biol Assoc UK 61: 509-527

Ward JE, Shumway SE (2004) Separating the grain from the chaff: particle selection in suspension- and deposit-feeding bivalves. J Exp Mar Biol Ecol 300:83-130

Wieking G, Kröncke I (2005) Is benthic trophic structure affected by food quality? The Dogger Bank example. Mar Biol 146:387-400

Wigham BD, Hudson IR, Billett DSM, Wolff GA (2003) Is long-term change in the abyssal Northeast Atlantic driven by qualitative changes in export flux? Evidence from selective feeding in deep-sea holothurians. Prog Oceanogr 59:409-441

Witte U, Wenzhöfer F, Sommer S, Boetius A and others (2003) In situ experimental evidence of the fate of a phytodetritus pulse at the abyssal sea floor. Nature 424: 763-766

Wolff GA, Billett DSM, Bett BJ, Holtvoeth J and others (2011) The effects of natural iron fertilisation on deep-sea ecology: the Crozet Plateau, southern Indian Ocean. PLOS ONE 6:e20697

Woulds C, Cowie GL, Levin LA, Andersson JH and others (2007) Oxygen as a control on seafloor biological communities and their roles in sedimentary carbon cycling. Limnol Oceanogr 52:1698-1709

Wu JP, Calvert SE, Wong CS (1999) Carbon and nitrogen isotope ratios in sedimenting particulate organic matter at an upwelling site off Vancouver Island. Estuar Coast Shelf Sci 48:193-203

Yamamuro M, Kayanne H (1995) Rapid direct determination of organic carbon and nitrogen in carbonate-bearing sediments with a Yanaco MT-5 CHN analyzer. Limnol Oceanogr 40:1001-1005

Yool A, Martin AP, Anderson TR, Bett BJ, Jones DOB, Ruhl HA (2017) Big in the benthos: future change of seafloor community biomass in a global, body size-resolved model. Glob Change Biol 23:3554-3566

Submitted: May 8, 2018; Accepted: October 4, 2018 Proofs received from author(s): December 5, 2018 